\title{
CTBP1 Gene
}

National Cancer Institute

\section{Source}

National Cancer Institute. CTBP1 Gene. NCI Thesaurus. Code C21400.

This gene plays a role in the repression of both transcription and cell proliferation. 